\title{
SISTEM INFORMASI INVENTORY BERBASIS WEB PADA PT. TELEKOMUNIKASI INDONESIA WITEL BANDUNG BARAT
}

\author{
Putri Utami ${ }^{1}$, Prayoga ${ }^{2}$, Bramanto Fajri Prakoso ${ }^{3}$ \\ Program Studi Sistem Informasi ${ }^{1,2,3}$ \\ Universitas Komputer Indonesia \\ Jl. Dipati Ukur No.112-116, Lebakgede, Kec. Coblong, Kota Bandung, Jawa Barat 40132 \\ putri.utami@email.unikom.ac.id ${ }^{1}$, prayoga@email.unikom.ac.id ${ }^{2}$, bramanto74@email.unikom.ac.id $^{3}$
}

\begin{abstract}
Abstrak
PT. Telkom Witel Bandung Barat merupakan satu-satunya BUMN telekomunikasi serta penyelenggara layanan telekomunikasi dan jaringan terbesar di Indonesia, dimana BUMN telekomunikasi harus selalu ditingkatkan perkembangannya demi menghasilkan layanan telekomunikasi dan jaringan yang berkualitas. Misalnya dengan cara menggunakan teknologi informasi saat ini. Pengolahan data inventory pada PT.Telkom Witel Bandung Barat tidak terintegrasi dengan baik, sehingga sulit dalam dalam pencarian data, adanya redundasi data serta lamanya pembuatan laporan. Metodologi yang digunakan dalam sistem informasi inventory ini adalah metodologi Prototype. Sedangkan metodologi pengumpulan data menggunakan metode Observasi dan Wawancara. Metode pengembangan menggunakan metode Terstruktur. Bahasa pemrograman yang digunakan adalah PHP dan database MySQL. Sistem informasi inventory dapat menampilkan data material, data penerimaan, data pengeluaran, data pengambilan dan data transaksi. Dengan diimplementasikannya sistem informasi inventory ini, diharapkan dapat memudahkan pihak PT.Telkom Witel Bandung Barat yang terkait dalam pelaksanaan sistem informasi inventory tersebut (mempercepat pencarian data, meminimalisir redudansi data serta mempercepat pembuatan laporan), sehingga dapat mencapai hasil yang maksimal serta dapat menunjang informasi dengan cepat dan akurat.
\end{abstract}

Keyword:

Sistem Informasi, Inventory

\begin{abstract}
PT. Telkom Witel West Bandung is the only stateowned company in the telecommunications and network sector in Indonesia, where SOEs can continue to develop to realize quality services and networks. Use it using information technology today. Inventory data processing at PT. West Witel Telkom is not well integrated, it is difficult to find data, including redundation of data and the length of time the report is made. The methodology currently in this inventory information system is Prototype, i.e. While the data uses observation and interview data. The method of development uses a structured method. The programming language is $P H P$ and MySQL database. Information inventory system can display material data, receipt data, expenditure data, retrieval data and transaction data. With the implementation of this inventory information system, it is expected to facilitate PT. Telkom Witel West Bandung is related to the application of information inventory systems (speeding up data search, minimizing data redundancy and speeding up report generation), can achieve maximum results and can support information quickly and accurately.
\end{abstract}

Keyword:

Information System, Inventory

\section{Pendahuluan}

Sistem inventory merupakan suatu aktivitas dalam proses pengolahan data barang yang terdapat di dalam suatu gudang. Sistem inventory mempunyai peran yang sangat besar terhadap sebuah instansi, 
sebab sistem inventory bisa menolong menanggulangi permasalahan pengolahan data barang dan mempermudah pelaporan data barang yang tersedia. Suatu instansi yang tidak mempunyai sistem inventory, akan mengalami sedikit permasalahan dalam pengolahan data barang contohnya, pada PT.Telkom Witel Bandung Barat yang menjalankan sistem pencatatan data inventory secara manual. Staff mengerjakan pendataan barang. Aktifitas pendataannya mencakup, pendataan barang baru datang, barang lama yang masih pantas dipakai, bahkan barang yang rusak dan seharusnya diganti, kemudian data tersebut diolah menjadi laporan data inventory terhadap pihak Mgr. Support dan Supply dengan menggunakan Microsoft excel. Proses pengumpulan data seperti ini tidak cukup efektif sebab dibutuhkan ketelitian, dalam pengumpulan data dengan jumlah barang yang tidak sedikit kerap kali menyebabkan terjadinya redundancy data (data ganda) dan dalam proses pengerjaan laporan data inventory membutuhkan progres yang lama sebab staff wajib membuat data baru. Persoalan hal yang demikian membuat staff mesti bekerja secara berulang-ulang untuk mendapatkan data yang ideal, contohnya pada kasus pembuatan laporan data inventory untuk pendataan barang baru yang akan diletakan pada ruangan yang tersedia, staff wajib melakukan pengecekan ulang pada keadaan barang yang tersedia di ruangan dan merevisi laporan inventory barang tersebut. Kegiatan Kerja Praktek ini merupakan pembangunan sistem inventory di PT.Telkom Witel Bandung Barat. Sistem yang akan dikembangkan bisa menyampaikan data secara realtime dan akses data yang kencang sehingga, jikalau ada barang yang baru masuk serta ada perubahan pada status barang karenanya pengguna bisa langsung mengakses data tersebut. Berdasarkan latar belakang diatas, maka penulis hendak merancang sebuah sistem informasi inventory untuk mendukung proses analisis dan perancangan Sistem Infromasi Inventory di PT.Telkom Witel Bandung Barat menjadi sistem yang lebih baik dan mengangkatnya menjadi materi ujian tengah semester mata kuliah metodologi penelitian.

\section{KAJIAN LITERATUR}

\section{II.1 Sistem}

Menurut Jogiyanto (2005) Sistem merupakan suatu jaringan kerja dari prosedur-prosedur yang saling berhubungan, berkumpul bersama-sama untuk melakukan suatu kegiatan atau menyelesaikan suatu sasaran tertentu. (Jogiyanto, 2005)

\section{II.2 Informasi}

Menurut George H. Bodnar (2000) Informasi merupakan sebuah data yang diolah kemudian menghasilkan sebuah dasar untuk mengambil suatu keputusan yang paling tepat. (Bodnar, 2000)

\section{II.2.1 Kualitas Informasi}

Kualitas informasi (quality of information) sangat dipengaruhi atau ditentukan oleh beberapa hal sebagai berikut:

\section{Relevan}

Seberapa jauh tingkat relevansi informasi pada suatu kejadian baik dari masa lalu, hari ini maupun masa depan. Informasi yang berkualitas akan mampu menunjukkan benang merah relevansi sebagai sebuah bentuk aktifitas yang konkrit dan mampu dilaksanakan, dan dibuktikan oleh siapa saja.

\section{Akurat (accuracy)}

Suatu informasi dikatakan berkualitas jika seluruh kebutuhan informasi tersebut telah tersampaikan (Completeness), seluruh pesan telah benar/sesuai (Correctness), serta sistem yang diinginkan oleh user (Security).

\section{Tepat Waktu (timeliness)}

Berbagai proses dapat diselesaikan dengan tepat waktu, laporan-laporan yang dibutuhkan dapat disampaikan tepat waktu.

\section{Ekonomis (economy)}

Informasi yang dihasilkan mempunyai daya tarik yang tinggi, serta biaya operasional untuk menghasilkan informasi tersebut minimal, informasi tersebut juga mampu memberikan dampak yang luas terhadap laju pertumbuhan ekonomi dan teknologi informasi.

\section{Efisien (efficiency)}

Suatu ukuran keberhasilan informasi yang memberikan dampak mendalam terhadap sebuah teknologi informasi.

6. Dapat Dipercaya (reliability) 
Informasi tersebut berasal dari sumber yang dapat dipercaya. Sumber tersebut juga telah teruji tingkat kejujurannya. Misalkan output suatu program komputer, bisa dikategorikan sebagai reliability, karena program komputer akan memberikan output sesuai dengan input yang diberikan, dan outputnya tidak pernah dipengaruhi oleh iming-iming jabatan, ataupun setumpuk nilai rupiah. (Kristanto, 2008)

\section{II.2.2 Siklus Informasi}

Data yang masih merupakan bahan mentah apabila tidak diolah maka data tersebut tidak akan berguna. Data tersebut akan berguna dan menghasilkan suatu informasi apabila diolah melalui suatu model. Model yang digunakan untuk mengolah data tersebut disebut dengan model pengolahan data atau lebih dikenal dengan nama siklus informasi atau siklus pengolahan data, coba perhatikan.

dapat dijelaskan bahwa data yang merupakan suatu kejadian yang menggambarkan kenyataan yang terjadi dimasukan melalui elemen input kemudian data tersebut akan diolah dan di proses menjadi suatu output dan output tersebut adalah informasi yang dibutuhkan. Informasi tersebut akan diterima oleh pemakai atau penerima kemudian penerima akan memberikan umpan balik yang berupa evaluasi terhadap informasi tersebut dan hasil umpan balik tersebut akan menjadi data yang akan dimasukan menjadi input kembali begitu seterusnya. (Sugiyono, 2005)

\section{II.3 Sistem Informasi}

Menurut Gordon B. Davis (1991) Sistem informasi merupakan sebuah sistem yang menerima inputan data lalu menerima instruksi dan juga merupakan pengolah data yang dijalankan melalui sebuah instruksi lalu mengeluarkan hasilnya. (Gordon, 1991)

\section{II.4 Inventory (Persediaan)}

Menurut Schroeder (2000) didalam bukunya menyatakan bahwa persediaan (inventory) adalah stock bahan yang digunakan untuk memudahkan produksi atau untuk memuaskan permintaan pelanggan. (Schroeder, 2000)

\section{II.5 Website}

Menurut M. Rudiyanto Arief (2011) website atau situs dapat diartikan sebagai kumpulan halamanhalaman yang digunakan untuk menampilkan informasi teks, gambar diam atau gerak animasi, suara, dan atau gabungan dari semuanya, baik yang bersifat statis maupun dinamis yang membentuk rangkaian bangunan yang saling terkait. (Rudianto, 2011)

\section{II.6 XАMPP}

Menurut Susanto (2004) Dalam pembuatan web secara offline dibutuhkan sebuah web server local (localhost). Hal ini berguna untuk mensimulasikan sebuah server sebenarnya (online). Pada web server yang akan diletakkan file beserta databasenya.

Web server yang digunakan kali ini adalah XAMPP yang merupakan komponen utama untuk server local. XAMPP merupakan perangkat lunak gratis, yang dapat digunakan oleh berbagai macam sistem operasi, dan merupakan kumpulan dari berbagai macam program. XAMPP berfungsi sebagai server yang dapat berdiri sendiri. XAMPP terdiri dari program MySQLdatabase, Apache HTTP Server, dan penerjemah bahasa lain yang dibuat dengan bahasa pemrograman Perl dan PHP. X (empat sistem operasi apapun), Apache, MySQL, PHP dan Perl merupakan kepanjangan dari XAMPP. (Susanto, 2004)

\section{II.7 PHP}

Menurut Betha Sidik (2014) PHP merupakan secara umum dikenal dengan sebagai bahasa pemrograman script - script yang membuat dokumen HTML secara on the fly yang dieksekusi di server web, dokumen HTML yang dihasilkan dari suatu aplikasi bukan dokumen HTML yang dibuat dengan menggunakan editor teks atau editor HTML, dikenal juga sebagai bahasa pemrograman server side". (Sidik, 2014)

\section{Metodologi}

Metode penelitian yang dilakukan yaitu dengan melakukan analisis terhadap sistem yang sedang 
berjalan, mengidentifikasi kebutuhan. Adapaun alat bantu yang digunakan adalah flowmap, diagram konteks, data flow diagram, kamus data, normalisasi, tabel relasi dan entity relationship diagram.

\section{Analisa dan Pembahasan}

\section{IV.1 Flowmap}

\section{A. Flowmap Login}

Gambaran fungsional dari suatu sistem yang akan dibangun sehingga dapat dipelajari oleh pengguna. Berikut merupakan Flowmap Sistem Informasi Inventory Berbasis Web pada PT Telkomunikasi Indonesia Witel Bandung Barat.

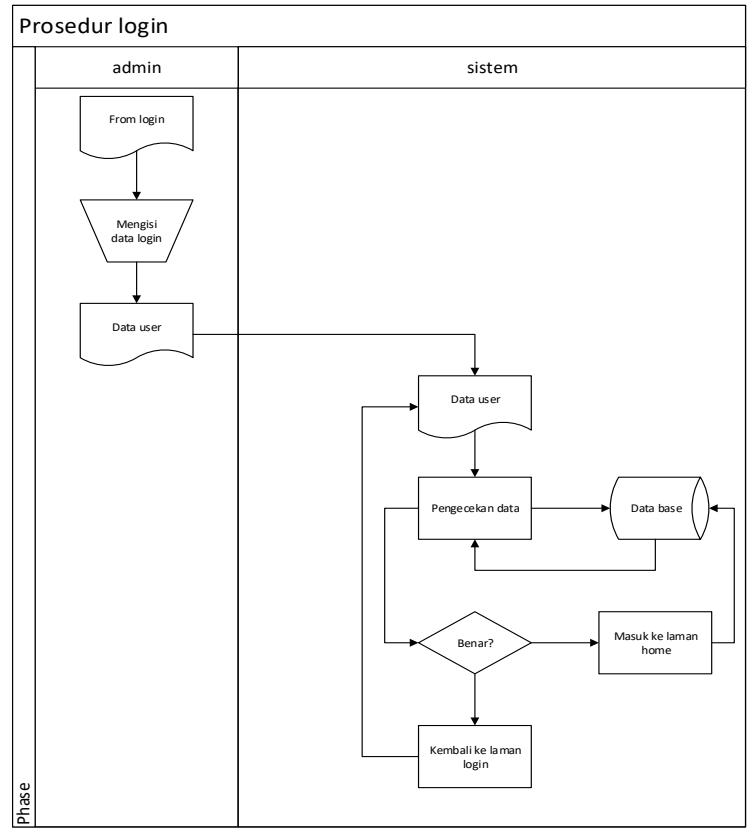

Gambar. 1 Flowmap Login yang diusulkan

1. Prosedur login

a. Buka web gudang, web akan langsung menampilkan halaman untuk login.

b. Masukkan user name, dan password

c. Lalu klik ok

d. jika pasword dan username benar maka akan masuk ke laman utama, jika salah memasukkan user name, maka akan muncul alert "username atau sandi salah" dan akan kembali ke laman login.

\section{A. Flowmap Penerimaan Material}

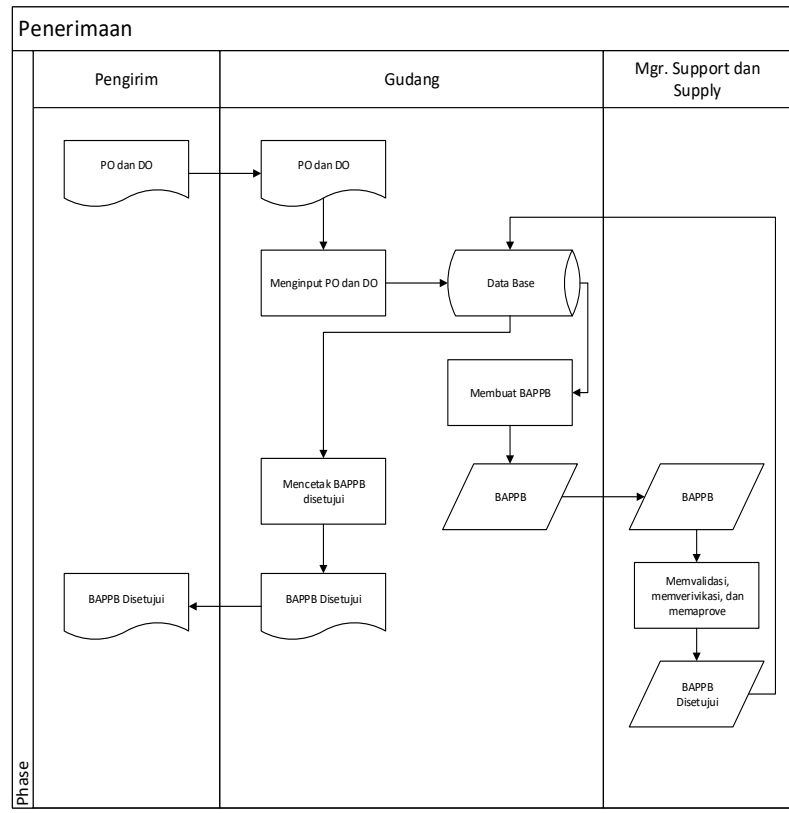

Gambar. 2 Flowmap Penerimaan Material yang diusulkan

2. Penerimaan

a. Petugas gudang menerima dan memeriksa dokumen penerimaan barang PO dan $\mathrm{DO}$ (volume, item, spesifikasi) dari pengirim barang

b. Petugas gudang menginput data PO dan DO yang diterima ke web.

c. Aplikasi akan menampilkan data PO dan DO untuk membuat BAPPB secara otomatis.

d. Mgr. Support dan supply dapat melihat data BAPPB dari aplikasi dan memverivikasi, memvalidasi, dan mengaprove BAPPB yang langsung disimpan kedatabase.

e. Petugas bisa langsung mencetak BAPPB dari web.

f. Menyerahkan BAPPB yang sudah divalidasi diberikan kepada pengirim barang. 
B. Flowmap Transaksi Antar Gudang

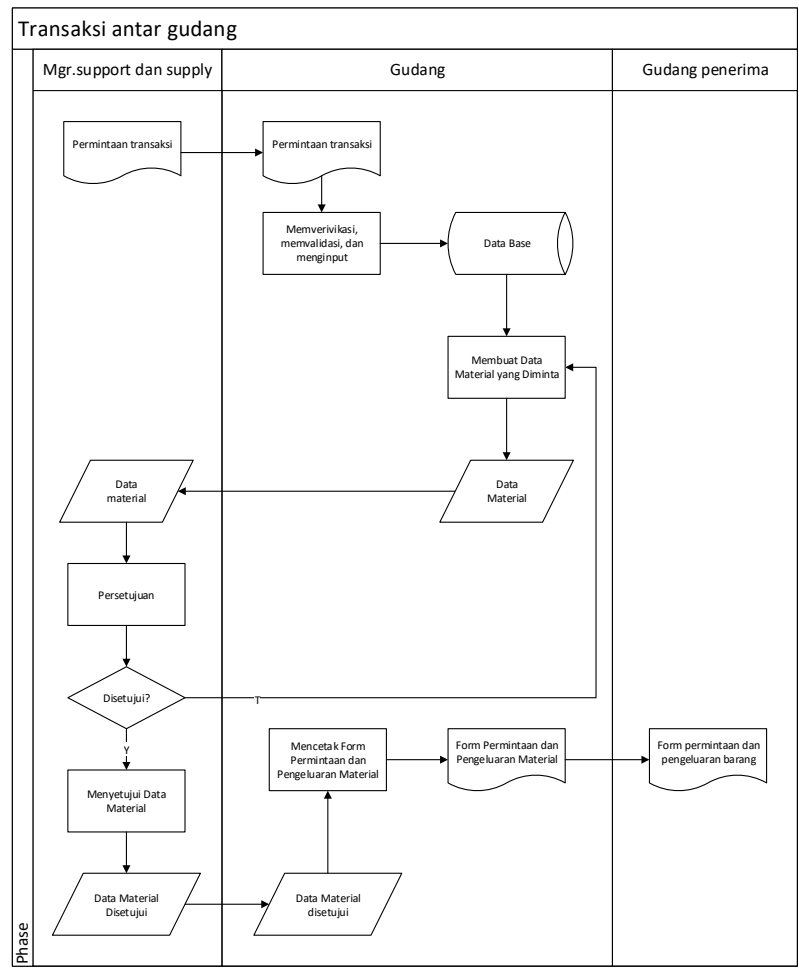

Gambar. 3 Flowmap Transaksi Antar Gudang yang diusulkan

3. Transaksi antar gudang

a. Mgr. Support dan Supply memberikan permintaan transaksi antar gudang kepada petugas gudang.

b. Petugas gudang, memverivikasi dan validasi permintaan, menginput permintaan di web dan langsung tersimpan di database.

c. Web akan menampilkan data material yang diajukan yang bisa dibuka oleh Mgr.Support dan Supply.

d. Mgr. Support dan Supply menyetujui permintaan, jika tidak setuju permintaan akan dikembalikan kepada petugas gudang untuk membuat ulang data material yang diminta.

e. Jika setuju maka petugas gudang pengirim mecetak form permintaan dan pengeluaran barang, dan menyerahkannya kepada gudang penerima. f. Petugas gudang penerima, menerima barang dan data barang.

C. Flowmap Pengembalian Material

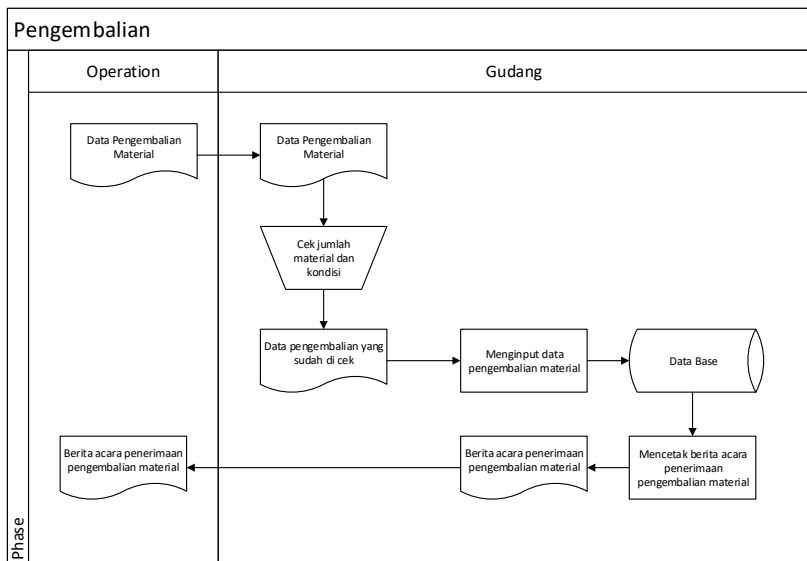

Gambar. 4 Flowmap Pengembalian Material yang diusulkan

4. Pengembalian material

a. Petugas gudang menerima pengembalian material dari operation.

b. Petugas gudang mengecek jumlah material dan kondisi material yang dikembalikan.

c. Petugas gudang menginput pengembalian material.

d. Petugas mencetak berita acara penerimaan pengembalian material dan menyerahkannya kepada operation. 
D. Flowmap Pengeluaran Material

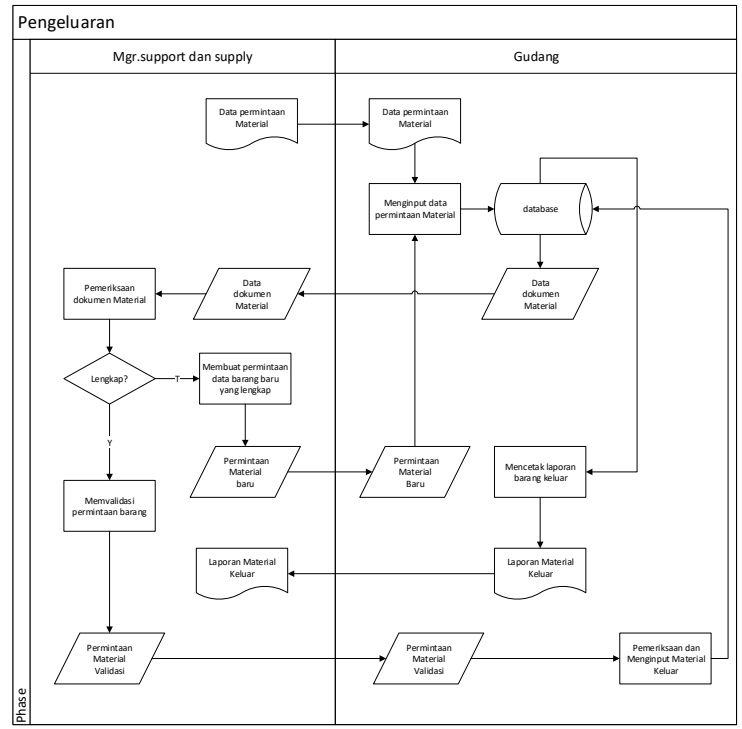

Gambar. 5 Flowmap Pengeluaran Material yang diusulkan

5. Pengeluaran

a. Petugas gudang menginput data permintaan material dari Mgr.Support dan Supply.

b. Petugas menginput data material ke web.

c. Web akan secara otomatis menampilkan data dokumen material.

d. Pemeriksaan dokumen permintaan barang, tanda tangan sesuai otorisasi, data-data barang yang akan dilakukan oleh Mgr.Support dan Supply.

e. Jika sesuai maka Mgr.Support dan Supply akan memvalidasi, jika tidak maka akan membuat permintaan barang baru yang lengkap.

f. Setelah permintaan validasi oleh Mgr.Support dan Supply terkait melalui web petugas gudang melakukan pemeriksaan barang keluar gudang dan melengkapi dengan dokumen yang diperlukan seperti : surat jalan, persetujuan permintaan dll.

g. Petugas gudang menginput barang keluar di web.

h. Petugas bisa langsung mencetak laporan barang keluar di web.

\section{E. Flowmap Stock Material}

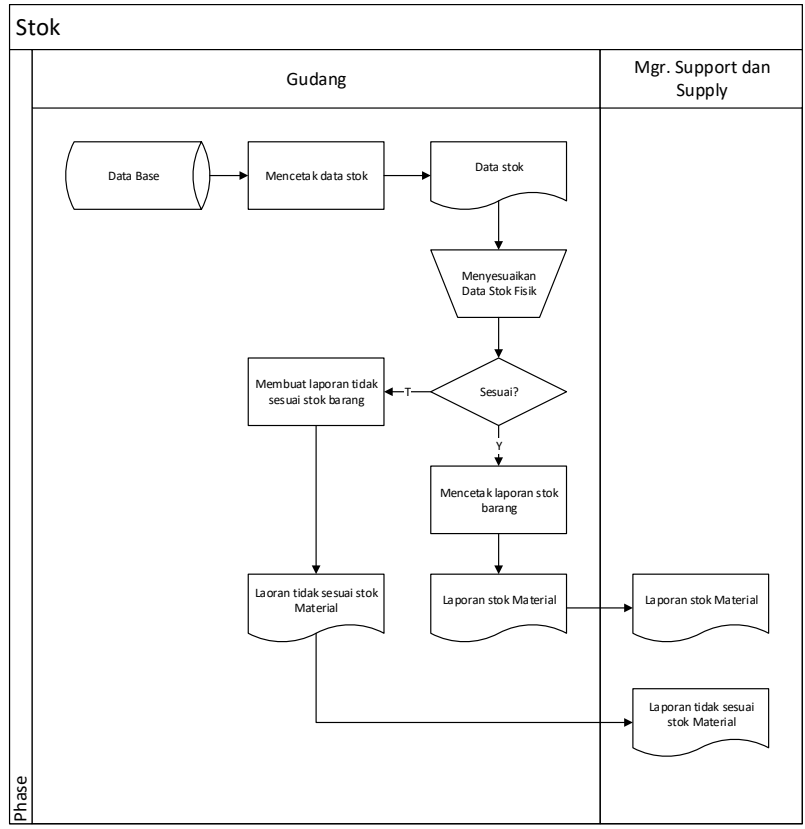

Gambar. 6 Flowmap Stock Material yang diusulkan

6. Stok

a. Petugas mencari data stok di web dan mencetak data stok.

b. Petugas gudang menyesuaikan dengan data stok fisik digudang.

c. Jika tidak sesuai maka ptugas gudang membuat laporan tidak sesuai dan diserahkan kepada Mgr.Support dan Supply. Jika sesuai maka petugas gudang akan menetak laporan dan mengirimnya ke Mgr. Support dan supply. 


\section{IV.2 Diagram Konteks}

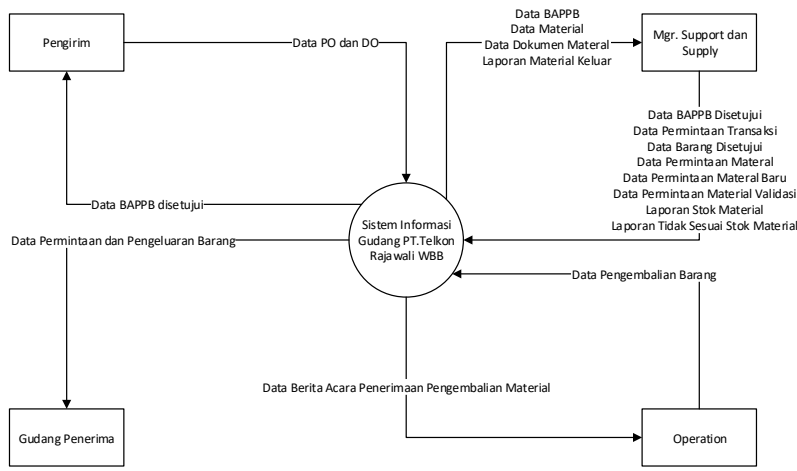

Gambar. 7 Diagram Konteks yang diusulkan

\section{IV.3 Data Flow Diagram (DFD)}

A. DFD Level 1

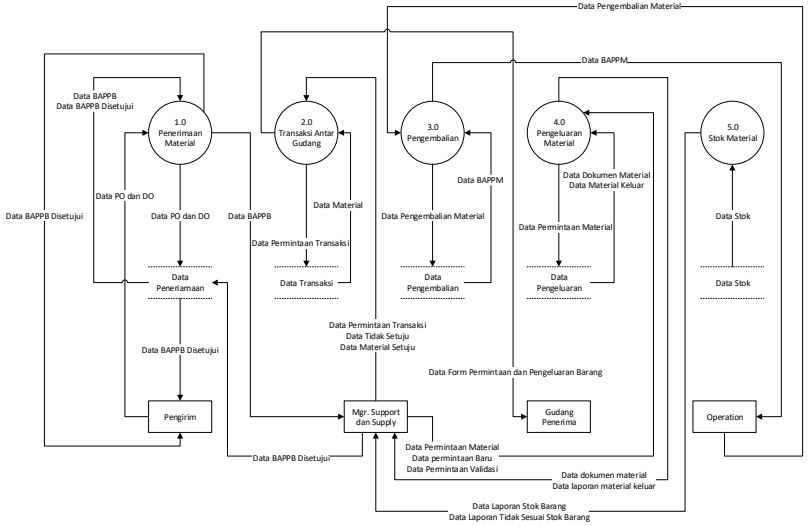

Gambar. 8 DFD Level 1
B. DFD Level 2 Proses 1

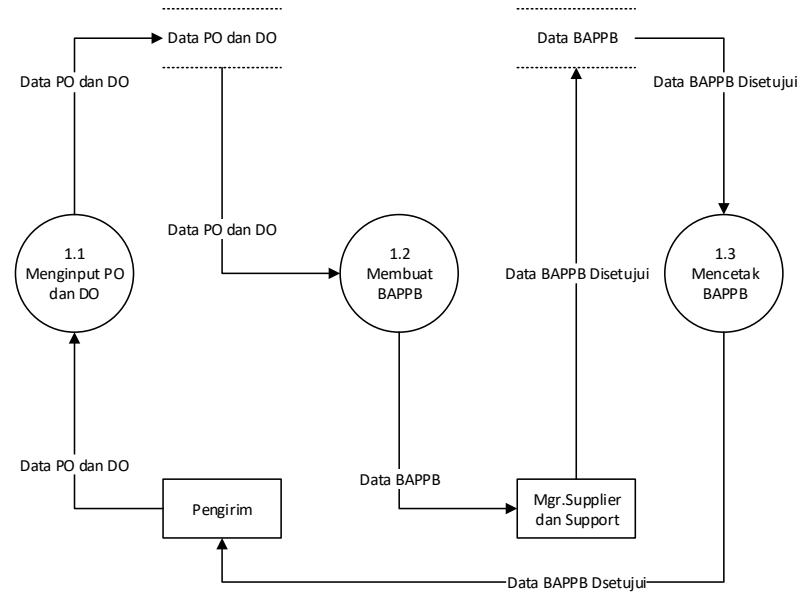

Gambar. 9 DFD Level 2 Proses 1

\section{DFD Level 2 Proses 2}

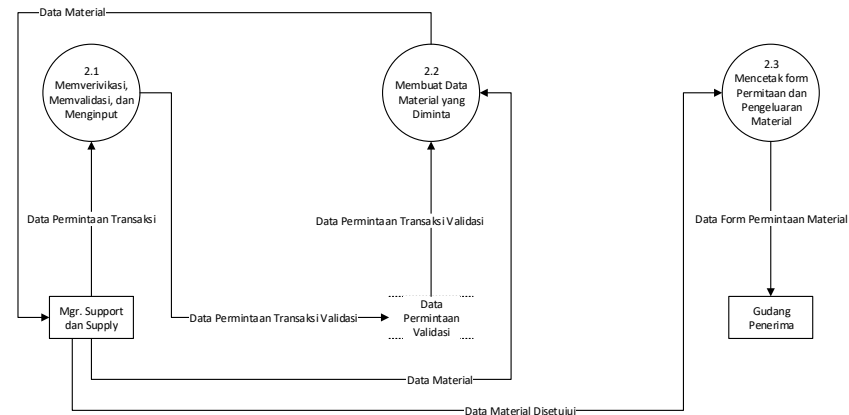

Gambar. 10 DFD Level 2 Proses 2

D. DFD Level 2 Proses 3

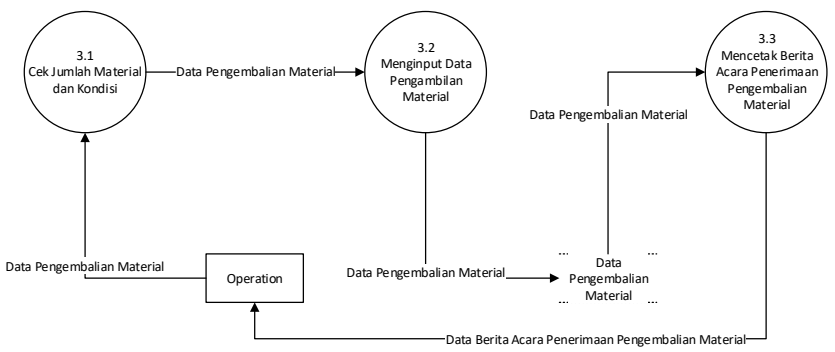

Gambar. 11 DFD Level 2 Proses 3

Putri Utami, Prayoga, Bramanto Fajri Prakoso 


\section{E. DFD Level 2 Proses 4}

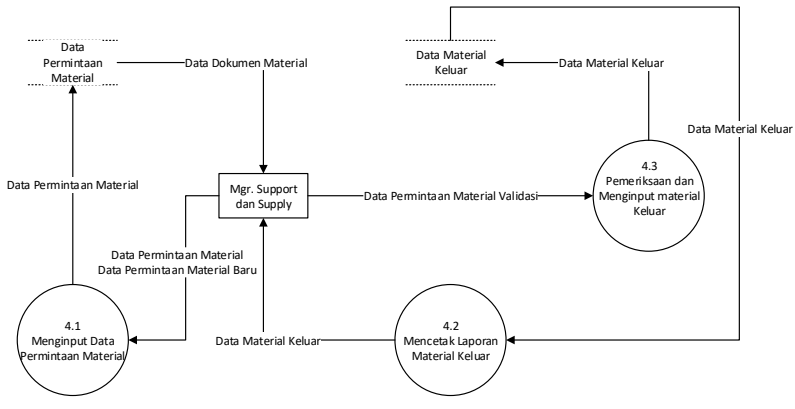

Gambar. 12 DFD Level 2 Proses 4

\section{F. DFD Level 2 Proses 5}

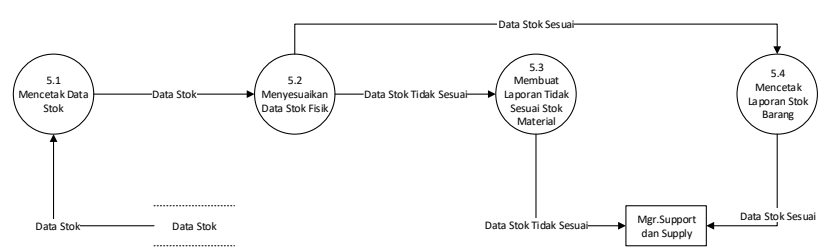

Gambar. 13 DFD Level 2 Proses 5

\section{IV.4 Kamus Data}

\begin{tabular}{|c|c|}
\hline $\begin{array}{l}\text { Nama } \\
\text { Dokumen }\end{array}$ & Data PO dan DO \\
\hline Deskripsi & $\begin{array}{c}\text { PO(Purchase } \\
\text { DO(Delivery Order) }\end{array}$ \\
\hline Sumber & Pengirim \\
\hline Aliran & 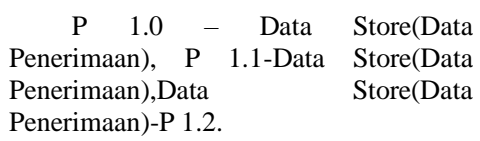 \\
\hline $\begin{array}{l}\text { Elemen } \\
\text { data/atribut }\end{array}$ & $\begin{array}{c}\text { Spesifikasi, } \quad \text { Volume, } \\
\text { Delivery, Gudang Tujuan }\end{array}$ \\
\hline $\begin{array}{l}\text { Nama } \\
\text { Dokumen }\end{array}$ & Data BAPPB \\
\hline Deskripsi & Pemeriksaan dan \\
\hline
\end{tabular}

\begin{tabular}{|c|c|}
\hline & Penerimaan Barang \\
\hline Sumber & Bagian Gudang \\
\hline Aliran & $\begin{array}{l}\text { P 1.0-Mgr.Support dan Supply, } \\
\text { Data Store(Data Penerimaan)-P 1.0, P } \\
\text { 1.2-Mgr. Supplier dan Support }\end{array}$ \\
\hline $\begin{array}{l}\text { Elemen } \\
\text { data/atribut }\end{array}$ & $\begin{array}{l}\text { Tgl_terima, nama_gudang, id_po, } \\
\text { id_do, pengirim, supplier, id_material, } \\
\text { id_penerimaan, id_pengembalian }\end{array}$ \\
\hline $\begin{array}{l}\text { Nama } \\
\text { Dokumen }\end{array}$ & Data Permintaan Transaksi \\
\hline Deskripsi & $\begin{array}{l}\text { Data Permintaan Untuk Melkaukan } \\
\text { Transaksi Antar Gudang }\end{array}$ \\
\hline Sumber & Mgr.Support dan Supply \\
\hline Aliran & P 2.0-Data Store(Data Transaksi) \\
\hline $\begin{array}{l}\text { Elemen } \\
\text { data/atribut }\end{array}$ & $\begin{array}{l}\text { Id_transaksi, } \\
\text { tgl_transaksi, nama_gudang }\end{array}$ \\
\hline
\end{tabular}

\begin{tabular}{|c|c|}
\hline $\begin{array}{l}\text { Nama } \\
\text { Dokumen }\end{array}$ & $\begin{array}{l}\text { Data } \\
\text { Validasi }\end{array}$ \\
\hline Deskripsi & $\begin{array}{l}\text { Data Permintaan Transaksi yang } \\
\text { Sudah Divalidasi }\end{array}$ \\
\hline Sumber & Petugas Gudang \\
\hline Aliran & $\begin{array}{l}\text { P 2.1-Data Store (Data } \\
\text { Permintaan Validasi), Data Store(Data } \\
\text { Permintaan Validasi)-P } 2.2\end{array}$ \\
\hline $\begin{array}{l}\text { Elemen } \\
\text { data/atribut }\end{array}$ & $\begin{array}{l}\text { Id_transaksi, id_material, } \\
\text { tgl_transaksi, nama_gudang }\end{array}$ \\
\hline
\end{tabular}

Putri Utami, Prayoga, Bramanto Fajri Prakoso 


\begin{tabular}{|c|c|}
\hline $\begin{array}{l}\text { Nama } \\
\text { Dokumen }\end{array}$ & Data Material \\
\hline Deskripsi & $\begin{array}{c}\text { Data Barang/Material yang } \\
\text { Berada Didalam Gudang }\end{array}$ \\
\hline Sumber & Petugas Gudang \\
\hline Aliran & $\begin{array}{lll} & \text { Data Store(Data Transaksi)-P 2.0, } \\
\text { P } & \text { 2.2-Mgr.Support dan } & \text { Supply, } \\
\text { Mgr.Support dan Supply-P } 2.2 & \end{array}$ \\
\hline $\begin{array}{l}\text { Elemen } \\
\text { data/atribut }\end{array}$ & $\begin{array}{l}\text { Id_material, tipe, spesifikasi, } \\
\text { volume }\end{array}$ \\
\hline $\begin{array}{l}\text { Nama } \\
\text { Dokumen }\end{array}$ & Data Permintaan Form Material \\
\hline Deskripsi & $\begin{array}{l}\text { Form Material yang diminta } \\
\text { kepada Gudang Penerima }\end{array}$ \\
\hline Sumber & Petugas Gudang \\
\hline Aliran & $\begin{array}{l}\text { P 2.0-Gudang Penerima, P2.3- } \\
\text { Gudang Penerima }\end{array}$ \\
\hline $\begin{array}{l}\text { Elemen } \\
\text { data/atribut }\end{array}$ & $\begin{array}{l}\text { Id_material, tipe, spesifikasi, } \\
\text { volume }\end{array}$ \\
\hline
\end{tabular}

\begin{tabular}{|c|c|}
\hline & Pengembalian Material \\
\hline Sumber & Petugas Gudang \\
\hline Aliran & $\begin{array}{l}\text { Data Store (Data Pengembalian)- } \\
\text { P3.0, P3.3-Operation }\end{array}$ \\
\hline $\begin{array}{l}\text { Elemen } \\
\text { data/atribut }\end{array}$ & $\begin{array}{l}\text { Id_pengembalian, } \\
\text { tgl_pengembalian, id_material, id_keluar }\end{array}$ \\
\hline $\begin{array}{l}\text { Nama } \\
\text { Dokumen }\end{array}$ & Data Permintaan Material \\
\hline Deskripsi & Data Material yang Diminta \\
\hline Sumber & Mgr. Support dan Supply \\
\hline Aliran & $\begin{array}{l}\quad \text { Mgr. Suppot dan Supply-P } \\
\text { 4.0,P4.0-Data House(Data Pengeluaran), } \\
\text { Mgr.Support dan Supply-P4.1, P4.1- } \\
\text { Data House(Data Permintaan Material) }\end{array}$ \\
\hline $\begin{array}{l}\text { Elemen } \\
\text { data/atribut }\end{array}$ & $\begin{array}{l}\text { Id_material, tipe, spesifikasi, } \\
\text { volume }\end{array}$ \\
\hline
\end{tabular}

\begin{tabular}{cc}
\hline \hline $\begin{array}{c}\text { Nama } \\
\text { Dokumen }\end{array}$ & Data Pengembalian Material \\
\hline \hline Deskripsi & Data material yang Dikebalikan \\
\hline \hline Sumber & Operation \\
\hline \hline Aliran & $\begin{array}{c}\text { Operation- P3.0, } \\
\text { Store(Data Pengembalian), P3.1-Data } \\
\text { Store(Data Pengembalian) }\end{array}$ \\
\hline \hline $\begin{array}{c}\text { Elemen } \\
\text { data/atribut }\end{array}$ & $\begin{array}{c}\text { Id_pengembalian, } \\
\text { tgl_pengembalian, id_material, id_keluar }\end{array}$ \\
\hline \hline & Data BAPPM \\
\hline \hline Nama & \\
\hline \hline Dokumen & Data Berita Acara Penerimaan \\
\hline \hline
\end{tabular}

\begin{tabular}{|c|c|}
\hline $\begin{array}{l}\text { Nama } \\
\text { Dokumen }\end{array}$ & Data Dokumen Material \\
\hline Deskripsi & $\begin{array}{l}\text { Data Kelengkapan Dokumen } \\
\text { Material }\end{array}$ \\
\hline Sumber & Petugas Gudang \\
\hline Aliran & \begin{tabular}{l}
\multicolumn{1}{c}{ Data Store(Data } \\
Material)-P4.0 ,Data \\
Permintaan Material)-Mgr.Support dan \\
Supply
\end{tabular} \\
\hline $\begin{array}{l}\text { Elemen } \\
\text { data/atribut }\end{array}$ & $\begin{array}{l}\text { Id_material, tipe, spesifikasi, } \\
\text { volume }\end{array}$ \\
\hline $\begin{array}{l}\text { Nama } \\
\text { Dokumen }\end{array}$ & Data Permintaan Material Baru \\
\hline Deskripsi & $\begin{array}{l}\text { Data Permintaan Material yang } \\
\text { Tidak Diseujui }\end{array}$ \\
\hline Sumber & Mgr Support dan Supply \\
\hline
\end{tabular}

Putri Utami, Prayoga, Bramanto Fajri Prakoso 


\begin{tabular}{|c|c|}
\hline Aliran & $\begin{array}{l}\text { Mgr.Support dan Supply-P4.0, } \\
\text { Mgr.Support dan Supply-P4.1 }\end{array}$ \\
\hline $\begin{array}{l}\text { Elemen } \\
\text { data/atribut }\end{array}$ & $\begin{array}{l}\text { Id_material, tipe, spesifikasi, } \\
\text { volume }\end{array}$ \\
\hline $\begin{array}{l}\text { Nama } \\
\text { Dokumen }\end{array}$ & Data Permintaan Material Validasi \\
\hline Deskripsi & $\begin{array}{r}\text { Data Permintaan Material yang } \\
\text { Divalidasi }\end{array}$ \\
\hline Sumber & Mgr. Support dan Supply \\
\hline Aliran & $\begin{array}{l}\text { Mgr. Support dan Supply-P4.3, } \\
\text { Mgr.Support dan Supply-P4.0 }\end{array}$ \\
\hline $\begin{array}{l}\text { Elemen } \\
\text { data/atribut }\end{array}$ & $\begin{array}{l}\text { Id_material, tipe, spesifikasi, } \\
\text { volume }\end{array}$ \\
\hline $\begin{array}{l}\text { Nama } \\
\text { Dokumen }\end{array}$ & Data Material Keluar \\
\hline Deskripsi & $\begin{array}{l}\text { Data Material yang Keluar dari } \\
\text { Gudang }\end{array}$ \\
\hline Sumber & Petugas Gudang \\
\hline Aliran & $\begin{array}{l}\text { Data Store(Data Pengeluaran)- } \\
\text { P4.0, Data Store(Data Material Keluar)- } \\
\text { P4.2, P4.3-Data Store(Data Material } \\
\text { Keluar), P4.2-Mgr. Support dan Supply }\end{array}$ \\
\hline $\begin{array}{l}\text { Elemen } \\
\text { data/atribut }\end{array}$ & \begin{tabular}{lr}
\multicolumn{1}{c}{ Id_keluar, } & tgl_keluar, \\
nama_gudang, & id_project, \\
Nama_project, nama_mitra, id_material, & \\
id-transaksi &
\end{tabular} \\
\hline
\end{tabular}

\begin{tabular}{cc}
\hline \hline $\begin{array}{c}\text { Nama } \\
\text { Dokumen }\end{array}$ & Data Stok \\
\hline \hline Deskripsi & Data Stok Material Digudang \\
\hline \hline Sumber & Petugas Gudang \\
\hline \hline Aliran & $\begin{array}{c}\text { Data Store(Data Stok)-P 5.0, Data } \\
\text { Store(Data Stok)-P 5.1, P5.1-P5.2, }\end{array}$ \\
\hline
\end{tabular}

\begin{tabular}{ccc}
\hline \hline $\begin{array}{c}\text { Elemen } \\
\text { data/atribut }\end{array}$ & $\begin{array}{l}\text { Id_barang, } \\
\text { volume }\end{array}$ \\
\hline \hline
\end{tabular}

\begin{tabular}{cc}
\hline \hline $\begin{array}{c}\text { Nama } \\
\text { Dokumen }\end{array}$ & Data Stok Sesuai \\
\hline \hline Deskripsi & $\begin{array}{l}\text { Data Stok yang Sesuai Dengan di } \\
\text { Data Base }\end{array}$ \\
\hline \hline Sumber & Petugas Gudang \\
\hline \hline Aliran & $\begin{array}{l}\text { P5.0-Mgr.Support dan Supply, } \\
\text { P5.2-P5.4, P5.4-Mgr.Support dan } \\
\text { Supply }\end{array}$ \\
\hline \hline & Id_barang, tipe, spesifikasi, \\
Elemen & volume \\
\hline \hline
\end{tabular}

\begin{tabular}{cc}
\hline \hline $\begin{array}{c}\text { Nama } \\
\text { Dokumen }\end{array}$ & Data Stok Tidak Sesuai \\
\hline \hline Deskripsi & $\begin{array}{c}\text { Data Stok yang Tidak Sesuai } \\
\text { Dengan di Data Base }\end{array}$ \\
\hline \hline Sumber & Petugas Gudang \\
\hline \hline Aliran & $\begin{array}{c}\text { P5.0-Mgr. Support dan Supply, } \\
\text { P5.2-P5.3, P5.3-Mgr. Support dan } \\
\text { Supply }\end{array}$ \\
\hline \hline $\begin{array}{c}\text { Elemen } \\
\text { data/atribut }\end{array}$ & Id_barang, tipe, spesifikasi, \\
\hline \hline
\end{tabular}

\section{IV.5 Normalisasi}

\section{IV.5.1 Bentuk tidak normal (Un-normal)}

Bentuk ini merupakan semua kumpulan data yang akan di record, tidak ada keharusan mengikuti format tertentu, dapat saja tidak lengkap atau terduplikasi datanya. Berikut ini bentuk data tidak normal:

Tgl_penerimaan, nama_gudang, id_po, no_do, pengirim, supplier, id_barang, id_penerimaan, id_pengembalian, id_pengeluaran, tgl_pengeluaran, nama_gudang, id_project, nama_project, nama_mitra, id_barang, id_transaksi, id_transaksi, id_barang,

Putri Utami, Prayoga, Bramanto Fajri Prakoso 
tgl_transaksi, nama_gudang, id_barang, tipe, spesifikasi, volume, id_pengembalian, tgl_pengembalian, id_barang, id_pengeluaran

\section{IV.5.2 Bentuk normal 1 (1-NF)}

Bentuk normal tahap kedua terpenuhi jika normalisasi tahap pertama terpenuhi dan semua atribut tidak termasuk dalam kunci primer secara utuh. Bentuk 1 dari sistem informasi ini adalah sebagai berikut:

Tgl_terima, nama_gudang, id_po, id_do, pengirim, supplier, id_barang, id_penerimaan, id_pengembalian, id_pengeluaran, tgl_pengeluaran, id_project, nama_project, nama_mitra, id_transaksi, tgl_transaksi, tipe, spesifikasi, volume, tgl_pengembalian.

\section{IV.5.3 Bentuk normal 2 (2_NF)}

Relasi dikatakan memenuhi kaidah normal tingkat kedua jika memenuhi kaidah 1-NF dan atribut bukan kunci harus bergantung pada atribut kunci. Pada bentuk normal tingkat kedua, semua atribut bukan kunci harus tergantung total pada semua atribut kunci, karena pada pembuatan bentuk normal kedua harus ditentukan dulu atribut kuncinya. Bentuk normal 2 sistem informasi ini adalah sebagai berikut:

a. Penerimaan $=$ id_penerimaan*, tgl_penerimaan, nama_gudang, no_po, no_do, pengirim, supplier

b. Pengeluaran $=$ id_keluar*, tgl_keluar, nama_gudang, id_project, nama_project, nama_mitra

c. Transaksi = id_transaksi*, tgl_transaksi, nama_gudang

d. Material = id_barang*, tipe, spesifikasi, volume

e. Pengembalian = id_pengembalian*, tgl_pengembalian

\section{IV.5.4 Bentuk normal 3 (3_NF)}

Bentuk normal 3 sistem informasi ini adalah sebagai berikut:

a. Penerimaan $=$ id_penerimaan*, tgl_terima, nama_gudang, no_po, no_do, pengirim, supplier, id_barang**, id_pengembalian**.

b. Pengeluaran $=$ id_pengeluaran*, tgl_pengeluaran, nama_gudang, id_project, nama_project, nama_mitra, id_barang**, id_transaksi**

c. Transaksi $=$ id_transaksi**, tgl_transaksi, nama_gudang, id_barang**

d. Material = id_barang*, tipe, spesifikasi, volume

e. Pengembalian = id_pengembalian*, tgl_pengembalian, id_barang**, id_pengeluaran**.

\section{IV.6 Entity Relationship Diagram (ERD)}

Pada Entity Relationship Diagram (ERD) hubungan antar file direlasikan dengan kunci relasi (Relational Key) yang merupakan kunci utama dari masing-masing file. ERD terdiri dari sekumpulan entitas-entitas yang saling berhubungan. Untuk menggambarkannya digunakan beberapa notasi dan symbol seperti, atribut dan relasi Entity Relationship Diagram. Pada sistem informasi PT. Telkom Witel Bandung Barat ini digambarkan sebagai berikut:

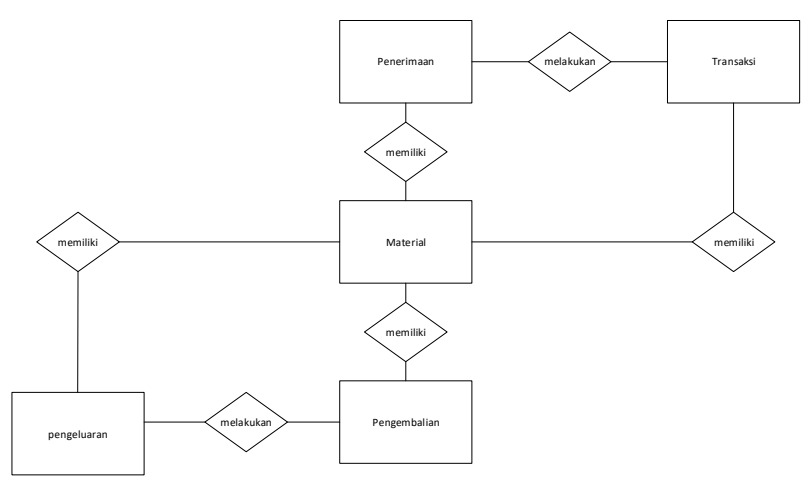

Gambar. 14 ERD yang diusulkan 


\section{IV.7 Tabel Relasi}

Adapun bentuk relasi antar tabel dari sistem informasi di PT. Telkom Witel Bandung Barat adalah sebagai berikut:

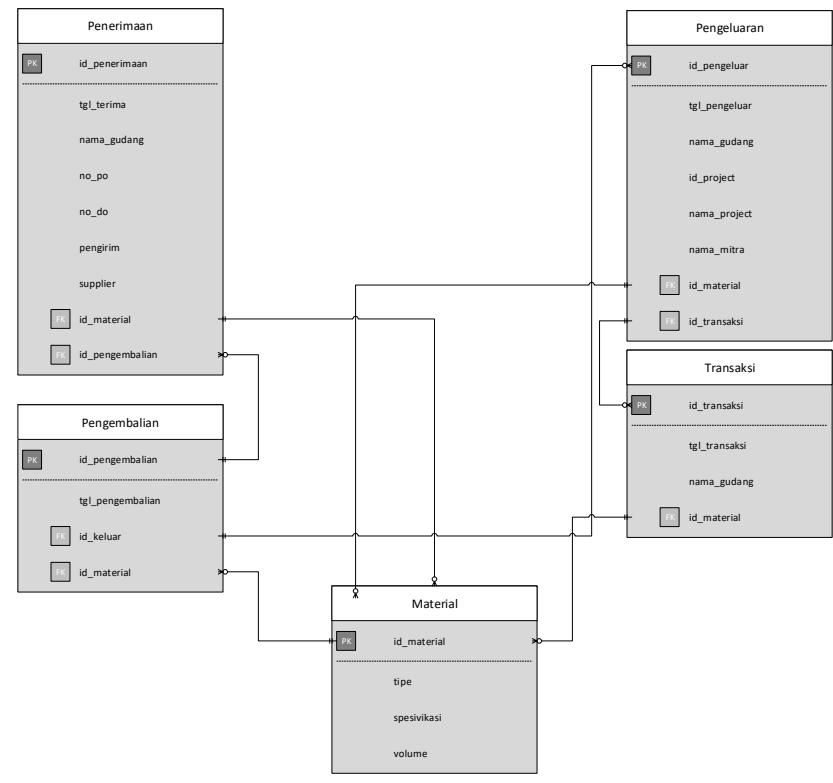

Gambar. 15 Tabel Relasi

\section{IV.8 Implementasi Antar Muka}

Berikut implementasi antar muka dari sistem yang telah dirancang:

\section{A. Form Login}

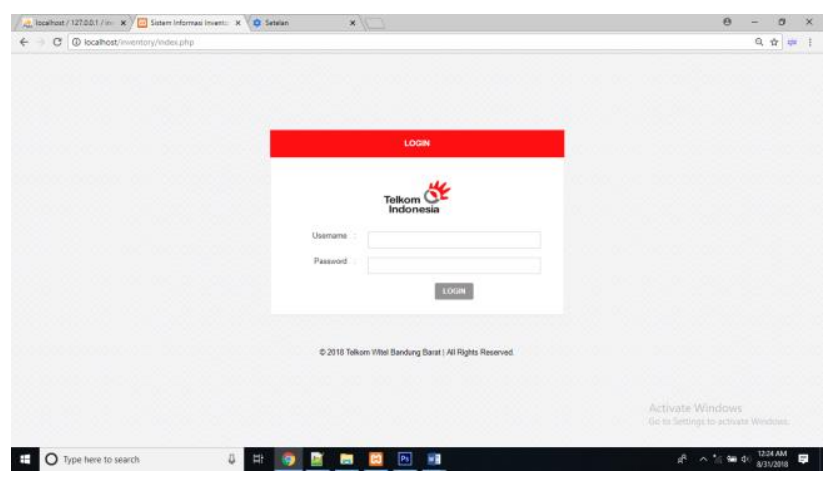

Gambar. 16 Form Login

Gambar di atas adalah Form login dari aplikasi yang di buat, yang terdiri dari User Name dan Password, sebelum admin masuk kedalam sistem maka admin harus memasukan User Name dan Password.

\section{B. Menu dashboard admin}

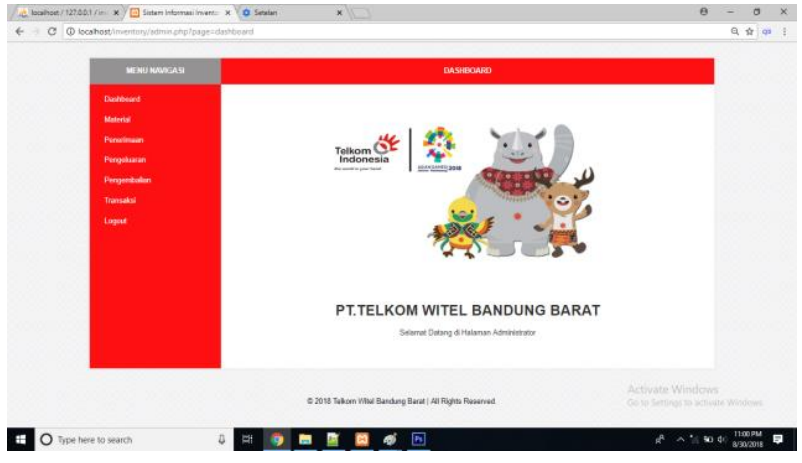

Gambar. 17 Menu dashboard admin

Pada Menu dashboard admin, terdapat data material, penerimaan, pengeluaran, pengembalian, transaksi dan logout.

\section{Menu data material}

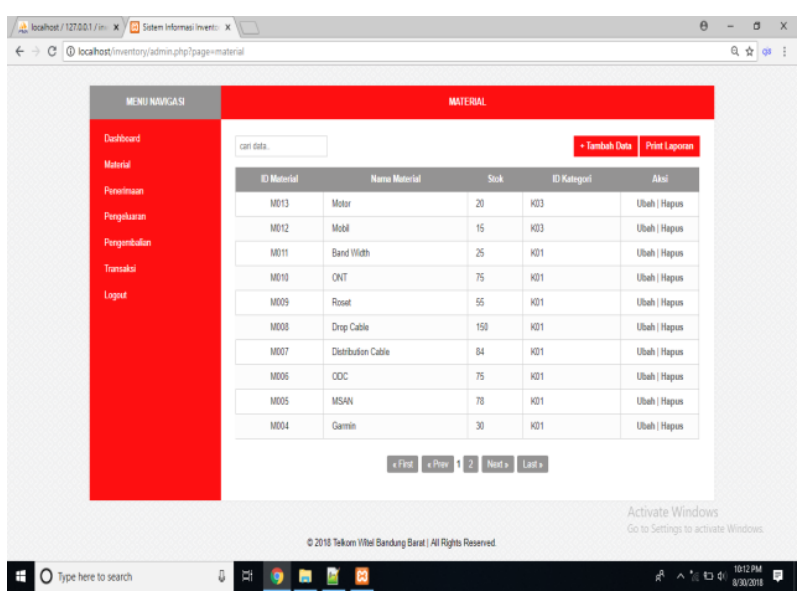

Gambar. 18 Menu data material

Pada Menu Data Material terdapat ID Material, Nama Material, Stok, ID Kategori, Aksi Ubah dan Hapus. 


\section{Form tambah data material}

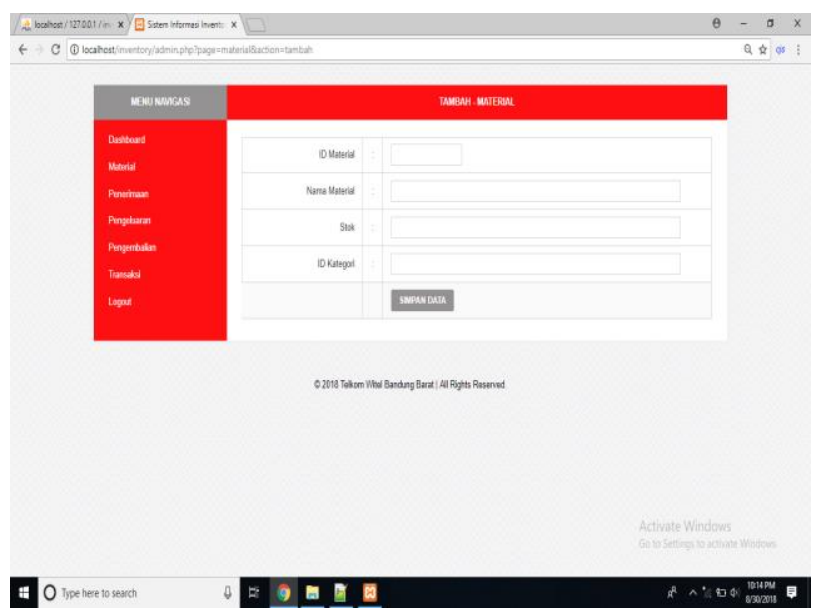

Gambar. 19 Form tambah data material

Pada Form Tambah Data Material terdapat ID Material, Nama Material, Stok, ID Kategori, Aksi Simpan Data.

\section{E. Menu data penerimaan material}

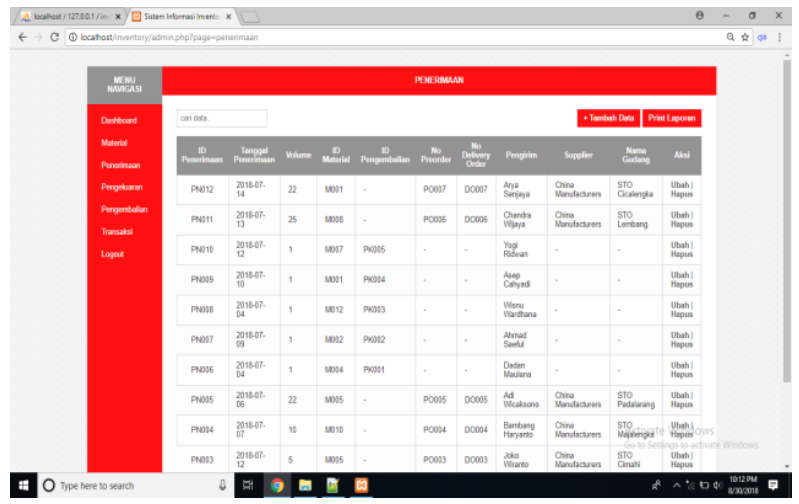

Gambar. 20 Menu data penerimaan material

Pada Menu Data Penerimaan Material terdapat ID Penerimaan, Tanggal Penerimaan, ID Material, ID Pengembalian, No.Preorder No.Delivery Order Pengirim Supplier, Nama Gudang Aksi Ubah dan Hapus.

\section{F. Form tambah data penerimaan material}

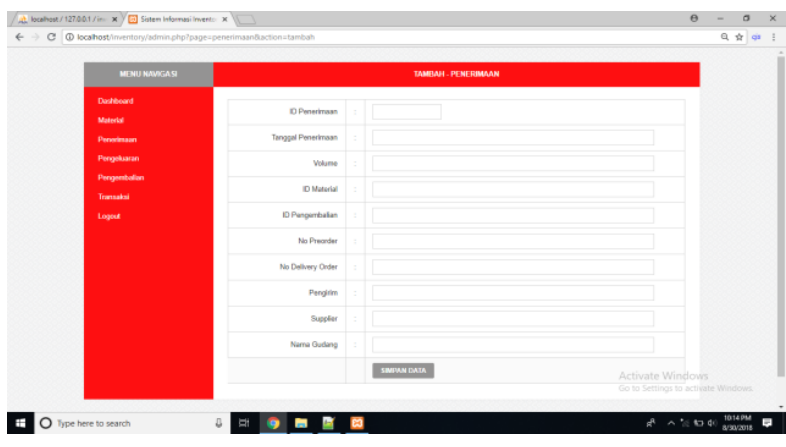
material

Gambar. 21 Form tambah data penerimaan

Pada Form Tambah Data Penerimaan Material terdapat ID Penerimaan, Tanggal Penerimaan, ID Material, ID Pengembalian, No.Preorder No.Delivery Order Pengirim Supplier, Nama Gudang Aksi Simpan Data.

\section{G. Menu data pengeluaran material}

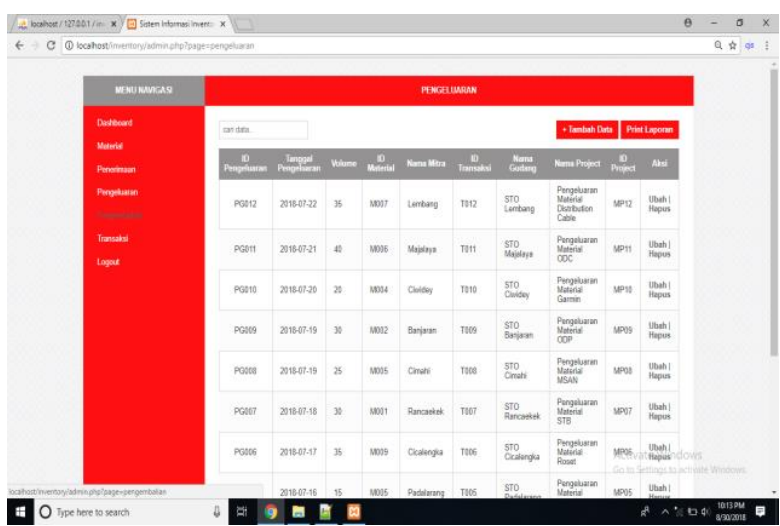

Gambar. 22 Menu data pengeluaran material

Pada Menu Data Pengeluaran Material terdapat ID Pengeluaran, Tanggal Pengeluaran, ID Material, Nama Mitra, ID Transaksi, Nama Gudang, Nama Project, ID Project, Aksi Ubah dan Hapus. 


\section{H. Form tambah data pengeluaran material}

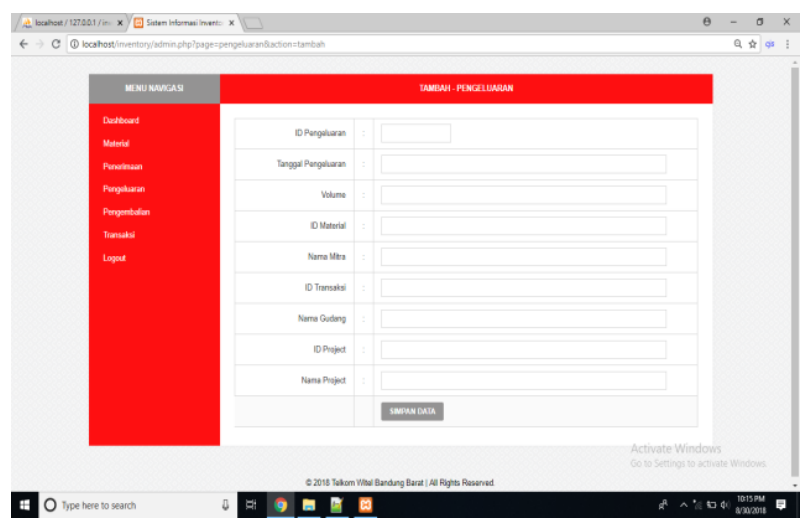

Gambar. 23 Form tambah data pengeluaran material

Pada Form Data Pengeluaran Material terdapat ID Pengeluaran, Tanggal Pengeluaran, ID Material, Nama Mitra, ID Transaksi, Nama Gudang, Nama Project, ID Project, Aksi Simpan Data.

\section{Menu data pengembalian material}

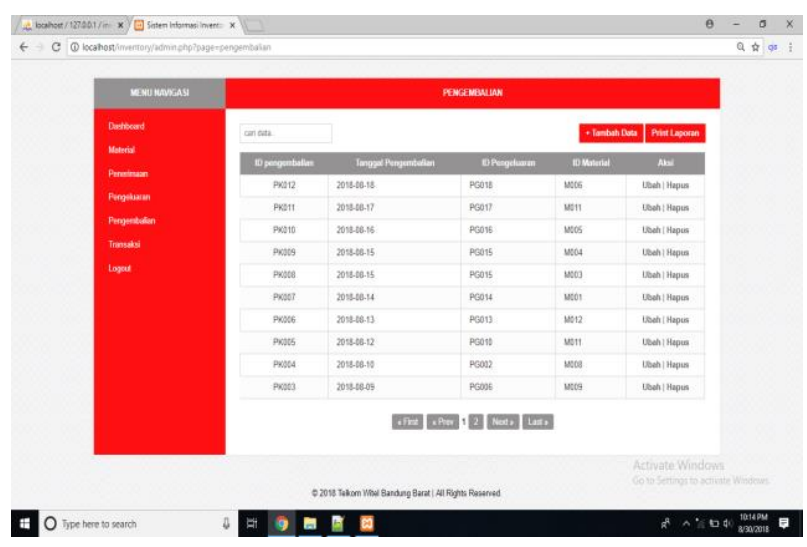

Gambar. 24 Menu data pengembalian material

Pada Menu Data Pengembalian terdapat ID Pengembalian, Tanggal Pengembalian, ID Pengeluaran, ID Material, Aksi Ubah dan Hapus.

\section{J. Form tambah data pengembalian material}

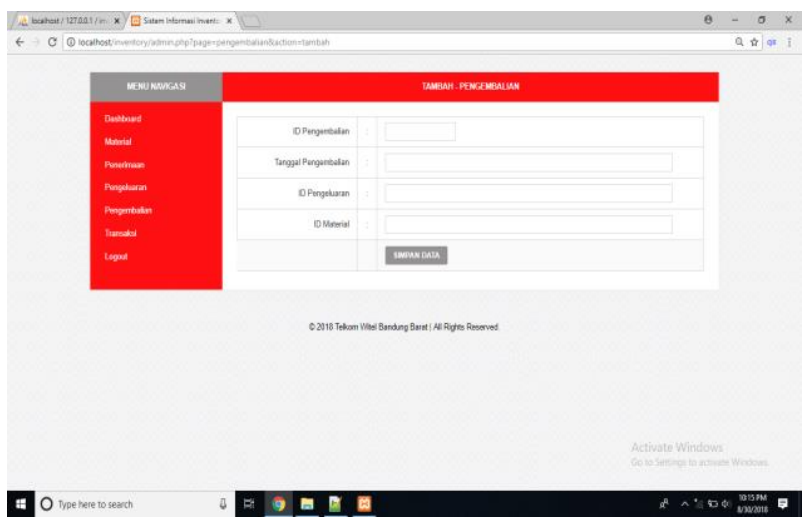

Gambar. 25 Form tambah data pengembalian material

Pada Form Tambah Data Pengembalian terdapat ID Pengembalian, Tanggal Pengembalian, ID Pengeluaran, ID Material, Aksi Simpan Data.

\section{K. Menu data transaksi antar gudang}

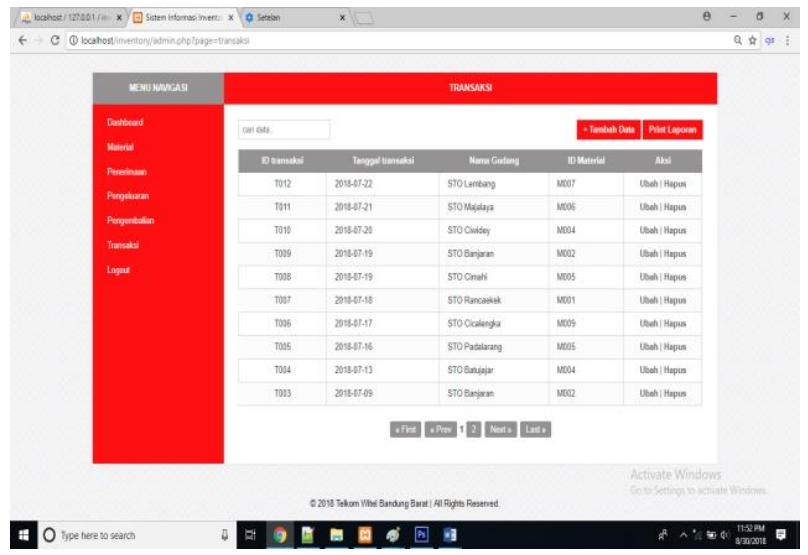

Gambar. 26 Menu data transaksi antar gudang

Pada Menu Tambah Data Transaksi Antar Gudang terdapat ID Transaksi, Tanggal Transaksi, Nama Gudang, ID Material, Aksi Ubah dan Hapus. 
L. Halaman form tambah data transaksi antar gudang

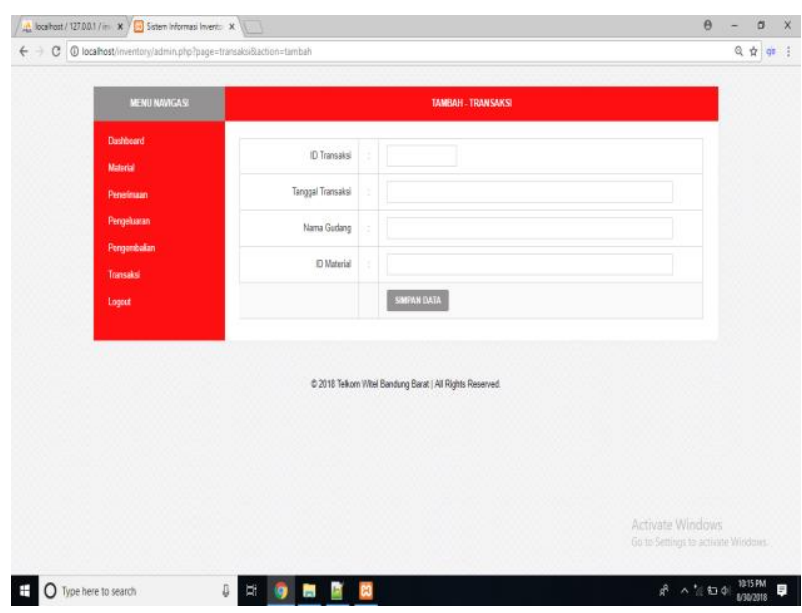

Gambar. 27 Halaman form tambah data transaksi antar gudang

Pada Form Tambah Data Transaksi Antar Gudang terdapat ID Transaksi, Tanggal Transaksi, Nama Gudang, ID Material, Aksi Simpan Data.

\section{IV.9 Pengujian}

Pengujian dilakukan untuk menjamin kualitas dan juga mengetahui kelemahan dari perangkat lunak. Tujuan dari pengujian ini adalah untuk menjamin bahwa perangkat lunak yang dibangun memiliki kualitas, yaitu mampu mempresentasikan kajian pokok dari spesifikasi, analisis, perancangan dan pengkodean dari perangkat lunak itu sendiri.
A. Rencana Pengujian

Berikut rencana pengujian yang akan dilakukan:

Tabel. 1 Tabel Rencana Pengujian

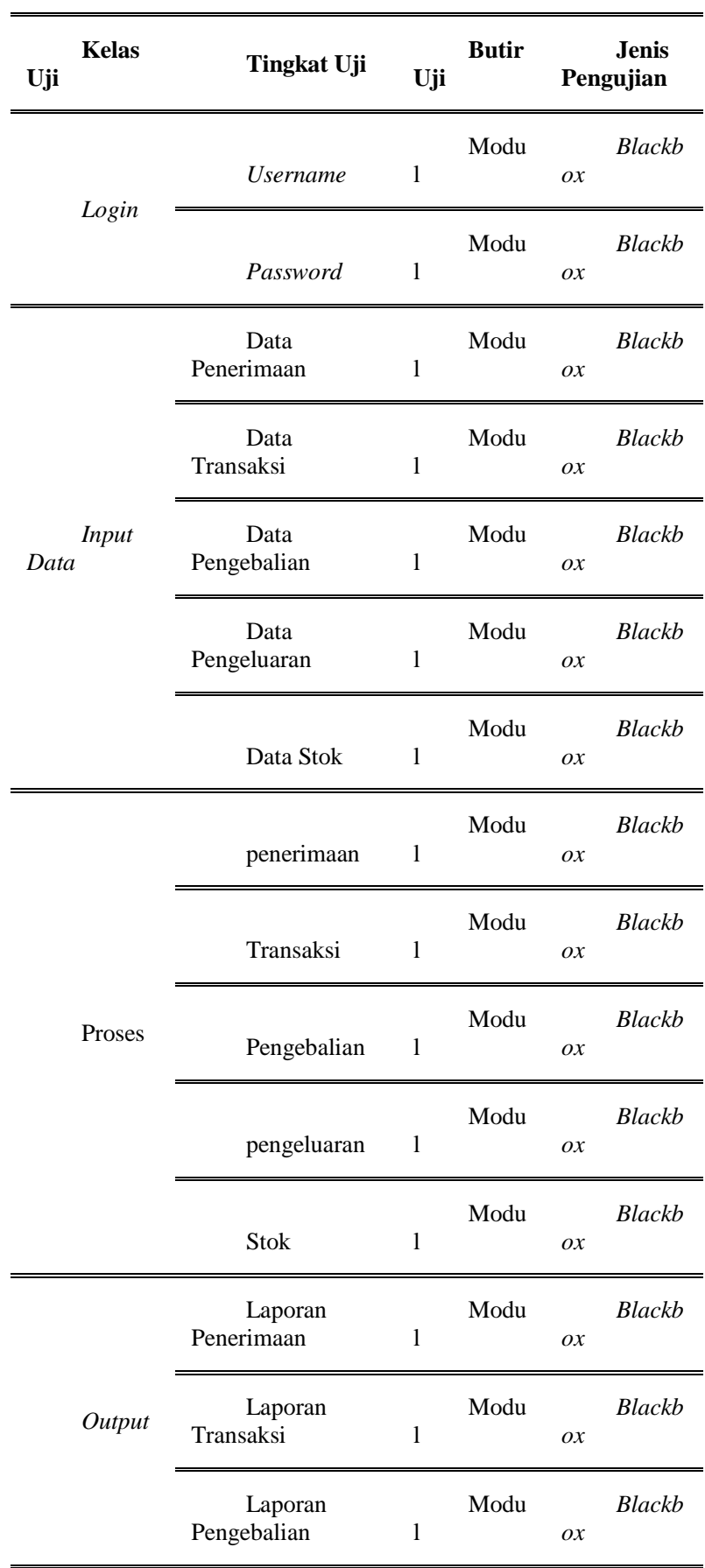




\begin{tabular}{|c|c|c|c|c|}
\hline $\begin{array}{l}\text { Laporan } \\
\text { Pengeluaran }\end{array}$ & 1 & Modu & $o x$ & Blackb \\
\hline & & Modu & & Blackb \\
\hline Laporan Stok & 1 & & $o x$ & \\
\hline
\end{tabular}

\section{B. Kasus Hasil Pengujian}

Berikut tabel pengujian dapat dilihat pada tabel dibawah ini:

a. Pengujian data login

Tabel. 2 Hasil Pengujian data login

Kasus dan Hasil Uji (Data Normal)

\begin{tabular}{|c|c|c|c|}
\hline $\begin{array}{r}\text { Data } \\
\text { Masukan }\end{array}$ & $\begin{array}{c}\text { Yang } \\
\text { Diharapkan }\end{array}$ & $\begin{array}{l}\text { Pengamat } \\
\text { an }\end{array}$ & ulan \\
\hline $\begin{array}{l}\text { Usern } \\
\text { ame } \\
\text { admin }\end{array}$ & \begin{tabular}{c}
\multicolumn{2}{c}{ Login } \\
sukses
\end{tabular} & \begin{tabular}{lr}
\multicolumn{2}{c}{ Login } \\
sukses dan \\
menu
\end{tabular} & rima ${ }^{[\checkmark] \text { Dite }}$ \\
\hline $\begin{array}{r}\text { Passw } \\
\text { ord : admin }\end{array}$ & & akses & $\underset{\text { ]Ditolak }}{[}$ \\
\hline
\end{tabular}

b. Pengujian input data

Tabel. 3 Hasil Pengujian Input data

Kasus dan Hasil Uji (Data Normal)

\begin{tabular}{c||c||c||c}
\hline \hline $\begin{array}{c}\text { Data } \\
\text { Masukan }\end{array}$ & $\begin{array}{c}\text { Yang } \\
\text { Diharapkan }\end{array}$ & tan Pengama & \multicolumn{2}{|c|}{ Kesimp } \\
\hline \hline
\end{tabular}

\begin{tabular}{|c|c|c|c|}
\hline $\begin{array}{r}\text { Mengisi } \\
\text { semua field } \\
\text { data material }\end{array}$ & $\begin{array}{l}\text { Muncul } \\
\text { pesan data } \\
\text { tersimpan dan } \\
\text { data material } \\
\text { bertambah di } \\
\text { database }\end{array}$ & \begin{tabular}{lr}
\multicolumn{2}{c}{ Muncul } \\
pesan data \\
tersimpan dan \\
data mata \\
material \\
bertambah di \\
database
\end{tabular} & $\begin{array}{c}\operatorname{rima}^{[\checkmark] \text { Dite }} \\
{ }_{\text {]Ditolak }}^{[}\end{array}$ \\
\hline $\begin{array}{l}\text { Mengisi } \\
\text { semua field } \\
\text { data } \\
\text { penerimaan }\end{array}$ & \begin{tabular}{l}
\multicolumn{2}{c}{ Muncul } \\
pesan data \\
tersimpan dan \\
data \\
penerimaan di \\
database
\end{tabular} & \begin{tabular}{l}
\multicolumn{2}{c}{ Muncul } \\
pesan data \\
tersimpan dan \\
data \\
penerimaan di \\
database
\end{tabular} & $\begin{array}{c}\operatorname{rima}^{[\checkmark] \text { Dite }} \\
\text { ]Ditolak }\end{array}$ \\
\hline $\begin{array}{l}r \text { Mengisi } \\
\text { semua field } \\
\text { data } \\
\text { pengeluaran }\end{array}$ & \begin{tabular}{l}
\multicolumn{2}{c}{ Muncul } \\
pesan data \\
tersimpan dan \\
data \\
pengeluaran di \\
database
\end{tabular} & \begin{tabular}{l}
\multicolumn{2}{c}{ Muncul } \\
pesan data \\
tersimpan dan \\
data \\
pengeluaran di \\
database
\end{tabular} & $\begin{array}{c}\operatorname{rima}^{[\checkmark] \text { Dite }} \\
\text { ]Ditolak }\end{array}$ \\
\hline $\begin{array}{l}\text { Mengisi } \\
\text { semua field } \\
\text { data } \\
\text { pengebalian }\end{array}$ & \begin{tabular}{l}
\multicolumn{2}{c}{ Muncul } \\
pesan data \\
tersimpan dan \\
data \\
pengembalian \\
bertambah di \\
database
\end{tabular} & \begin{tabular}{l}
\multicolumn{2}{c}{ Muncul } \\
pesan data \\
tersimpan dan \\
data \\
pengembalian \\
bertambah di \\
database
\end{tabular} & $\begin{array}{c}\operatorname{rima}^{[\checkmark] \text { Dite }} \\
\text { ]Ditolak }\end{array}$ \\
\hline $\begin{array}{r}\text { Mengisi } \\
\text { semua field } \\
\text { data transaksi }\end{array}$ & \begin{tabular}{l}
\multicolumn{2}{c}{ Muncul } \\
pesan data \\
tersimpan dan \\
data transaksi \\
bertambah di \\
database
\end{tabular} & \begin{tabular}{l}
\multicolumn{2}{c}{ Muncul } \\
pesan data \\
tersimpan dan \\
data transaksi \\
bertambah di \\
database
\end{tabular} & $\begin{array}{l}\text { rima }^{[\checkmark] \text { Dite }} \\
\text { ]Ditolak }\end{array}$ \\
\hline
\end{tabular}

Kasus dan Hasil Uji (Data Salah)

\begin{tabular}{|c|c|c|c|}
\hline $\begin{array}{c}\text { Data } \\
\text { Masukan }\end{array}$ & $\begin{array}{c}\text { Yang } \\
\text { Diharapkan }\end{array}$ & $\begin{array}{l}\text { Penga } \\
\text { matan }\end{array}$ & pulan \\
\hline $\begin{array}{l}\text { Mengoso } \\
\text { ngkan salah } \\
\text { satu field pada } \\
\text { proses tambah } \\
\text { data }\end{array}$ & 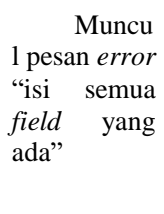 & \begin{tabular}{lr} 
& \multicolumn{2}{c}{ Muncu } \\
1 pesan & error \\
"isi & semua \\
field & yang \\
ada" &
\end{tabular} & $\begin{array}{l}{ }^{[\checkmark] \text { Dit }} \\
\text { erima } \\
\text { ]Ditolak }\end{array}$ \\
\hline $\begin{array}{l}\text { Tidak } \\
\text { mengisi nama } \\
\text { pelajaran }\end{array}$ & $\begin{array}{lr} & \text { Muncu } \\
1 \text { pesan } & \text { error } \\
\text { "isi } & \text { field } \\
\text { tidak } & \text { boleh }\end{array}$ & \begin{tabular}{lr}
\multicolumn{2}{c}{ Muncu } \\
1 pesan & error \\
"isi & field \\
tidak & boleh
\end{tabular} & $\begin{array}{c}\text { erima }^{[\checkmark] \text { Dit }} \\
{[}\end{array}$ \\
\hline
\end{tabular}

Putri Utami, Prayoga, Bramanto Fajri Prakoso 


\begin{tabular}{l||l||l||l}
\hline \hline & $\begin{array}{l}\text { kosong isi } \\
\text { lagi disini”. }\end{array}$ & $\begin{array}{l}\text { kosong isi } \\
\text { lagi disini”. }\end{array}$ & JDitolak \\
\hline \hline
\end{tabular}

c. Pengujian data proses

Tabel. 4 Hasil Pengujian data proses

\section{Kasus dan Hasil Uji (Data Normal)}

\begin{tabular}{|c|c|c|c|}
\hline $\begin{array}{r}\text { Data } \\
\text { Masukan }\end{array}$ & $\begin{array}{c}\text { Yang } \\
\text { Diharapkan }\end{array}$ & atan Pengam & ulan Kesimp \\
\hline $\begin{array}{l}\text { Mengis } \\
\text { i semua field } \\
\text { penerimaan }\end{array}$ & \begin{tabular}{l}
\multicolumn{2}{c}{ Muncul } \\
pesan simpan \\
berhasil dan \\
data \\
penerimaan \\
bertambah.
\end{tabular} & \begin{tabular}{l}
\multicolumn{2}{c}{ Muncul } \\
pesan simpan \\
berhasil dan \\
data \\
penerimaan \\
bertambah.
\end{tabular} & $\begin{array}{c}\operatorname{ima}{ }^{[\checkmark] \text { Diter }} \\
\text { ]Ditolak }\end{array}$ \\
\hline $\begin{array}{l}\text { Mengis } \\
\mathrm{i} \quad \text { seluruh } \\
\text { field } \\
\text { transaksi }\end{array}$ & $\begin{array}{l}\text { Muncul } \\
\text { pesan simpan } \\
\text { berhasil dan } \\
\text { data transaksi } \\
\text { bertambah. }\end{array}$ & $\begin{array}{l}\text { Muncul } \\
\text { pesan simpan } \\
\text { berhasil dan } \\
\text { data transaksi } \\
\text { bertambah. }\end{array}$ & $\begin{array}{c}\text { ima }{ }^{[\checkmark] \text { Diter }} \\
\text { ]Ditolak }\end{array}$ \\
\hline $\begin{array}{l}\text { Mengis } \\
\mathrm{i} \quad \text { seluruh } \\
\text { field } \\
\text { pengebalian }\end{array}$ & \begin{tabular}{l}
\multicolumn{2}{c}{ Muncul } \\
pesan simpan \\
berhasil dan \\
data \\
pengembalian \\
bertambah.
\end{tabular} & \begin{tabular}{l}
\multicolumn{2}{c}{ Muncul } \\
pesan simpan \\
berhasil dan \\
data \\
pengembalian \\
bertambah.
\end{tabular} & $\begin{array}{c}\operatorname{ima}{ }^{[\checkmark] \text { Diter }} \\
\text { ]Ditolak }\end{array}$ \\
\hline $\begin{array}{l}\text { Mengis } \\
\mathrm{i} \quad \text { seluruh } \\
\text { field } \\
\text { pengeluaran }\end{array}$ & \begin{tabular}{l}
\multicolumn{2}{c}{ Muncul } \\
pesan simpan \\
berhasil dan \\
data \\
pengeluaran \\
bertambah.
\end{tabular} & \begin{tabular}{l}
\multicolumn{2}{c}{ Muncul } \\
pesan simpan \\
berhasil dan \\
data \\
pengeluaran \\
bertambah.
\end{tabular} & $\begin{array}{c}\text { ima }{ }^{[\checkmark] \text { Diter }} \\
\text { ]Ditolak }\end{array}$ \\
\hline $\begin{array}{l}\text { Mengis } \\
\mathrm{i} \quad \begin{array}{r}\text { seluruh } \\
\text { field }\end{array} \text { stok }\end{array}$ & \begin{tabular}{l}
\multicolumn{2}{c}{ Muncul } \\
pesan simpan \\
berhasil dan \\
datar stok \\
bertambah.
\end{tabular} & \begin{tabular}{lr}
\multicolumn{2}{c}{ Muncul } \\
pesan simpan \\
berhasil dan \\
datar stok \\
bertambah.
\end{tabular} & $\begin{array}{c}\operatorname{ima}^{[\checkmark] \text { Diter }} \\
\text { ]Ditolak }\end{array}$ \\
\hline
\end{tabular}

Kasus dan Hasil Uji (Data Salah)

\begin{tabular}{c||c||c||c}
\hline $\begin{array}{c}\text { Data } \\
\text { Masukan }\end{array}$ & $\begin{array}{c}\text { Yang } \\
\text { Diharapkan }\end{array}$ & $\begin{array}{c}\text { Penga } \\
\text { matan }\end{array}$ & Kesimp \\
\hline \hline
\end{tabular}

\begin{tabular}{|c|c|c|c|}
\hline $\begin{array}{l}\text { Mengoson } \\
\text { gkan salah satu } \\
\text { field stok. }\end{array}$ & $\begin{array}{l}\quad \text { Tidak } \\
\text { dapat } \\
\text { menyimpan } \\
\text { data stok. }\end{array}$ & $\begin{array}{l}\text { Tidak } \\
\text { dapat } \\
\text { menyimpan } \\
\text { data stok. }\end{array}$ & $\begin{array}{l}\text { ima }{ }^{[\checkmark] \text { Diter }} \\
\text { ]Ditolak }\end{array}$ \\
\hline
\end{tabular}

d. Pengujian data output

Tabel. 5 Hasil Pengujian data output

Kasus dan Hasil Uji (Data Normal)

\begin{tabular}{|c|c|c|c|}
\hline $\begin{array}{l}\text { Data } \\
\text { Masukan }\end{array}$ & $\begin{array}{c}\text { Yang } \\
\text { Diharapkan }\end{array}$ & $\begin{array}{l}\text { Pengama } \\
\text { tan }\end{array}$ & ulan \\
\hline \begin{tabular}{l}
\multicolumn{2}{c}{ Cetak } \\
laporan data \\
penerimaan.
\end{tabular} & $\begin{array}{l}\text { Mendown } \\
\text { load dan } \\
\text { menampilkan } \\
\text { data } \\
\text { penerimaan. }\end{array}$ & $\begin{array}{l}\text { Mendown } \\
\text { load dan } \\
\text { menampilkan } \\
\text { data } \\
\text { penerimaan. }\end{array}$ & $\begin{array}{c}\operatorname{rima}^{[\checkmark] \text { Dite }} \\
\text { ]Ditolak }\end{array}$ \\
\hline \begin{tabular}{l}
\multicolumn{2}{c}{ Cetak } \\
laporan \\
transaksi
\end{tabular} & $\begin{array}{l}\text { Mendown } \\
\text { load dan } \\
\text { menampilkan } \\
\text { data transaksi. }\end{array}$ & $\begin{array}{l}\text { Mendown } \\
\text { load dan } \\
\text { menampilkan } \\
\text { data transaksi. }\end{array}$ & $\begin{array}{l}\text { rima }{ }^{[\checkmark] \text { Dite }} \\
\text { ]Ditolak }\end{array}$ \\
\hline $\begin{array}{l}\text { Cetak } \\
\text { laporan data } \\
\text { pengembalian }\end{array}$ & $\begin{array}{l}\text { Mendown } \\
\text { load dan } \\
\text { menampilkan } \\
\text { data } \\
\text { pengembalian }\end{array}$ & $\begin{array}{l}\quad \text { Mendown } \\
\text { load } \\
\text { menampilkan } \\
\text { data } \\
\text { pengembalian }\end{array}$ & $\begin{array}{l}\text { rima }{ }^{[\checkmark] \text { Dite }} \\
\text { ]Ditolak }\end{array}$ \\
\hline \begin{tabular}{l}
\multicolumn{2}{c}{ Cetak } \\
laporan data \\
pengeluaran
\end{tabular} & $\begin{array}{l}\text { Mendown } \\
\text { load dan } \\
\text { menampilkan } \\
\text { data } \\
\text { pengeluaran }\end{array}$ & $\begin{array}{l}\text { Mendown } \\
\text { load dan } \\
\text { menampilkan } \\
\text { data } \\
\text { pengeluaran }\end{array}$ & $\begin{array}{c}\operatorname{rima}^{[\checkmark] \text { Dite }} \\
\text { ]Ditolak }\end{array}$ \\
\hline \begin{tabular}{l}
\multicolumn{2}{c}{ Cetak } \\
laporan data \\
stok
\end{tabular} & $\begin{array}{l}\text { Mendown } \\
\text { load dan } \\
\text { menampilkan } \\
\text { data stok }\end{array}$ & $\begin{array}{l}\text { Mendown } \\
\text { load dan } \\
\text { menampilkan } \\
\text { data stok }\end{array}$ & $\begin{array}{c}\text { rima }{ }^{[\checkmark] \text { Dite }} \\
\text { ]Ditolak }\end{array}$ \\
\hline
\end{tabular}

Putri Utami, Prayoga, Bramanto Fajri Prakoso 


\begin{tabular}{|c|c|c|c|}
\hline \multicolumn{4}{|c|}{ Kasus dan Hasil Uji (Data Salah) } \\
\hline $\begin{array}{r}\text { Data } \\
\text { Masukan }\end{array}$ & $\begin{array}{c}\text { Yang } \\
\text { Diharapkan }\end{array}$ & $\begin{array}{l}\text { Pengam } \\
\text { atan }\end{array}$ & $\underset{\text { pulan }}{\text { Kesim }}$ \\
\hline \begin{tabular}{l}
\multicolumn{1}{c}{ Nilai } \\
belum di input \\
oleh petugas \\
gudang
\end{tabular} & \begin{tabular}{l}
\multicolumn{1}{c}{ Data } \\
Tidak \\
ditampilkan
\end{tabular} & \begin{tabular}{l}
\multicolumn{1}{c}{ Data } \\
Tidak \\
ditampilkan
\end{tabular} & $\begin{array}{c}\operatorname{rima}^{[\checkmark] \text { Dite }} \\
\text { ]Ditolak }\end{array}$ \\
\hline
\end{tabular}

\section{Kesimpulan Pengujian}

Berdasarkan hasil pengujian dengan metode pengujian black box berdasar uji sampel diatas, dapat ditarik kesimpulan bahwa sistem informasi inventory PT.Telkom witel Bandung Barat yang berupa perangkat lunak ini terbebas dari kesalahan serta menghasilkan output yang sesuai dengan harapan.

\section{KESIMPULAN DAN SARAN}

\section{V.1 Kesimpulan}

Dari hasil pembahasan yang telah di uraikan pada bab-bab sebelumnya, maka dapat ditarik kesimpulan sebagai berikut:

1. Sistem yang dirancang ini adalah Sistem Informasi Inventory pada bagian gudang. Sistem ini dapat memberikan beberapa kelebihan yaitu efisien dan efektif dalam pengolahan informasi dan pengelolaan data persediaan barang.

2. Sistem Informasi Inventory yang dibangun sudah dapat mendukung pelayanan pengelolaan barang di gudang dan menghasilkan laporan yang baik.

3. Pencatatan data yang sama hanya dilakukan sekali, hal ini menghindari duplikasi data sehingga kinerja dan waktu yang digunakan dalam pengelolaan barang-barang lebih efektif dan efisien. Pelayanan gudang menjadi lebih optimal karena bila terjadi kesalahan dalam pencatatan data maka user atau admin gudang dengan dapat segera mengetahui dan memperbaiki.

\section{V.2 Saran}

Adapun saran untuk pengembangan sistem yang telah dibuat ini adalah sebagai berikut :

1. Untuk pengembangan selanjutnya diharapkan tidak hanya mencakup data barang material, data transaksi antar gudang, data stok gudang, data barang penerimaan, data barang pengeluaran, dan data barang pengembalian saja karena masih banyak lagi pengembangan yang lain yang masih bisa dikembangkan dalam sistem informasi inventory.

2. Pada pengembangan sistem informasi inventory ini akan lebih bervariatif lagi jika tidak hanya dibangun dengan menggunakan bahasa berbasis pemrograman PHP dan database MySql.

3. Pada pengembangan sistem informasi inventory ini akan lebih baik jika tidak hanya di implementasikan pada PT.Telkom Witel Bandung Barat saja.

\section{REFERENSI}

Arief, M. (2011). Pemrograman Web Dinamis Menggunakan PHP Dan MySQL. Yogyakarta: AndiPublisher.

Bodnar, G. H. (2000). Sistem Informasi Akutansi, Diterjemahkan oleh Amir Abadi jusuf dan R. M Tambunan, Edisi Keenam, Buku Satu. Jakarta: Salemba Empat.

Gordon, B. D. (1991). Kerangka Dasar Sistem Informasi Manajemen Bagian 1. Jakarta: PT. Pustaka Binamas Pressindo.

Jogiyanto, H. (2005). Analisis dan Desain Sistem Informasi : Pendekatan Terstruktur Teori dan Praktek Aplikasi Bisnis. Yogyakarta: Andi.

Kristanto, A. (2008). Perancangan Sistem Informasi dan aplikasinya. Yogyakarta: Gava Media.

Rudianto, A. M. (2011). Pemrograman Web Dinamis Menggunakan PHP dan MySQL. Yogyakarta: Andi Offset.

Schroeder, R. (2000). Pengambilan Keputusan Dalam Suatu Fungsi Operasi, Edisi Ketiga. Jakarta: Erlangga. 
Sidik, B. (2014). Pemrograman Web dengan Php. Solo: Santika Kencana.

Sugiyono. (2005). Metode Penelitian Kuantitatif Kualitatif dan $R \& D$. Bandung: Alfabeta.

Susanto, A. (2004). Sistem Informasi Manajemen konsep dan pengembangannya. Bandung: Lingga Jaya. 